\title{
THE CULTURAL FOUNDATION OF RESOURCES, THE RESOURCE FOUNDATION OF POLITICAL CULTURES: AN EXPLANATION FOR THE OUTCOMES OF TWO GENERAL STRIKES
}

\author{
Victoria Johnson
}

\begin{abstract}
American general strikes have produced divergent outcomes. The Seattle general strike failed to win concessions in 1919. Shipyard contracts were cancelled and the post-war economic depression hit Seattle earlier than other ports. Yet, in San Francisco the general strike contributed to winning concessions in 1934, including the first coast wide contract in American history. In this paper I identify two processes integral to the explanation of these differing outcomes -- the ways in which a specific type of political culture, which I call workplace collectivism, was both determining of and determined by resources. First, workplace collectivism served as a foundation for the creation of economic resources. Interacting with favorable state actions, it was crucial to success in the San Francisco case, and to the institutionalization of this political culture. Second, the viability and transmission of workplace collectivism was determined by economic resources, increasing strategic options in San Francisco but limiting them in the Seattle case. Interacting with unfavorable political climate and state actions, concessions were not won in Seattle, resulting in the demise of this political culture.
\end{abstract}

We knew that the economic crisis of 1920-21 came to us a year before it came to others. And that our shipyard workers drifted to other cities to look for work. The young, the daring, the best fighters went...So the composition of our labor movement changed. The life died out of a dozen "workers' enterprises" which were part of our "inevitable road to socialism." Overexpanded cooperatives went bankrupt in a storm of recriminations. Business firms that had courted the Union Record with advertisements to capture the workers' trade now sensed our weakness and pressed for control of our columns. Workers fought each other for jobs and not the capitalists for power.

Seattle, Washington

Anna Louise Strong

I Change Worlds

We've had strikes on the Waterfront since 1934, but never again have the bosses dared to shoot our men down in cold blood.

San Francisco, California

Harry Bridges,

The Big Strike 


\section{INTRODUCTION}

In 1919 a five day general strike took place in Seattle, Washington. ${ }^{1}$ Its purpose was to show support for striking metal trades workers whose wages had been cut by a state agency that subsidized shipyards for war production. The Seattle general strike failed to win concessions for the metal trades workers. Shipyard contracts were cancelled in response to it and the post-war economic depression hit Seattle earlier than other ports.

Yet, in San Francisco a three day general strike contributed to winning concessions in 1934. It was called to support maritime workers who had organized a coast wide strike for union recognition and other concerns. The post-general strike concessions won through the National Longshoremen's Board were more generous than the first agreement proposed by a Roosevelt appointed committee a few months earlier. This included the first coast wide contract in American history and joint control of hiring halls by employers and employees, but with a union dispatcher, a figure central to the operations of the hall and thus to control of the workplace.

General strikes have been called labor's most powerful weapon, yet as the Seattle case illustrates, the use of this tactic is no guarantee of success. The question emerges -- why different outcomes? An attempt to answer this question must begin with the recognition of differences. In Seattle key players were metal trades workers challenging an agency of the state in contrast to maritime workers who challenged organized employers along the West Coast. The political and social climate was different in post-war 1919 as opposed to the depression of the 1930s. State actors responded to the general strikes in these differing social and political contexts.

Yet despite the distinctions, there are common features among these cases that provide an analytical lens for explaining their outcomes. In both cases workers instrumental to the emergence of the precipitating strikes and the general strikes shared an orientation toward political action with a number of similarities. In fact, there was an historical linkage between the two cases due to occupational networks.

This political culture, which I call workplace collectivism, constituted a cluster of ideational

tendencies and practices apparent in the organizational forms, strategies, tactics and goals employed by unionists in Seattle and maritime workers in San Francisco and other West Coast ports. Focusing on the impact of this political culture as it interacts with political climate, state actions and economic structures, allows for the recognition of two processes integral to the differing outcomes of these general strikes, and to identifying the ways in which cultural forms shape collective action.

First, this study traces the lineage of workplace collectivism, including the geographical, occupational and resource dependence of its agents who were involved in these strikes. Resources are defined as the ideational and physical material necessary for cultural production and/or communication. Occupational networks and the presence of specific types of occupational structures are included in this definition. Analysts of collective action have noted the relationship between political and economic resources and the generation and decline of social movements (Oberschall 1973; McCarthy \& Zald, 1973, 1977; Tilly, 1978; McAdam 1982; Jenkins and Perrow 1977; Jenkins,1999) but resources are rarely directly linked to political culture as an analytically distinct phenomenon.

\footnotetext{
${ }^{1}$ A general strike is a walk out by workers in enough key industries to stop the functioning of a city or region. In other words, the location is systematically shut down through the noncooperation of crucial segments of the labor force. The dynamics of a general strike necessitates that labor assert general authority over the distribution of essential goods and services.
} 
Second, it illustrates how organizational practices endemic to this cultural form generated economic resources. Current studies mostly focus on how culture facilitates or constrains movement mobilization and solidarity through ideation, with an emphasis on the construction of collective identity and framing techniques (Snow et al. 1986, 1988, 1992; Melucci 1989, 1995; Friedman and McAdam 1992; Larana et al.,1994; Johnston and Klandermans,1995; Bromley and Cutchin 1999). Aside from mobilization through ideational forms that attract new participants or conscience constituencies, the generation of economic resources has been explained though the resource mobilization and political process models of external elite patronage (McCarthy \& Zald 1973,1977; Jenkins and Perrow 1977; Jenkins1999) or the indigenous generation of movements which in turn elicit elite support (McAdam 1982). This study shows how workplace collectivism not only provided an ideational resonance for mobilization and solidarity, but also how its organizational practices generated economic resources crucial to winning concessions in the San Francisco case.

Focusing on a cultural form as integral to the explanation of outcomes in these general strikes differs from most historical studies. They often recognize the influence of a political culture of labor radicalism in both Seattle and San Francisco, yet implicitly or explicitly employ structural determinist models to explain the outcomes. There have been individual case studies (Freidheim 1964; Eliel, 1934; Quinn 1979, Selvin 1996), discussion of the Seattle and San Francisco general strikes as part of larger histories (O'Conner 1935; Bernstein 1970; Larrowe 1972; Sales 1976; Nelson 1990; Raineri 1991; Magden 1991; Berner 1991) and noncomparative histories (Crook 1931, 1960; Brecher 1997).

The first section of this paper provides a description of the workplace collectivist lineage and its transmission through occupational networks between the Pacific Northwest and the San Francisco Bay Area. Then an overview of both cases is presented, highlighting the impact of political culture as it interacts with political climate, state actions and economic structures to explain strike outcomes. In the final section I analyze the resource foundation of political culture and the cultural foundation for the generation of resources. Current approaches to the cultural analysis of collective action are reviewed and their utility for explaining the role of political culture in these cases is discussed. I conclude by proposing a "locational" model of cultural production.

\section{WORKPLACE COLLECTIVISM: ORIGIN AND TRANSMISSION}

Political culture, generally speaking, describes shared orientations toward political action. It can be distinguished from social movement cultures as 1) it exists without the presence of social movements although it may be drawn upon by movement actors, and 2) it is a much more diffuse than the focused ideologies, doctrines and programs that are constructed by social movements. The political cultures in Seattle and San Francisco consisted of ideational tendencies related to a lineage of labor radicalism which descends through the Knights of Labor in the nineteenth century, to the Industrial Workers of the World (IWW) in the early twentieth century, to the International Longshoremen's and Warehousemen's Union (ILWU) in the 1930s. I call this lineage "workplace collectivism."

Workplace collectivism cannot be reduced to one ideological orientation, rather it is a diffuse political culture that can be identified through tendencies toward five distinguishing

\footnotetext{
2 The word radical is used here to communicate something different from militancy. Militant action denotes being combative or aggressive to further a cause, but is not the same as radical action seeks some type of transformation of social structures. In the case of workplace collectivism, worker ownership and/or control of the workplace represents the goal of structural transformation in the relations between capital and labor.
} 
characteristics: (1) the primary goal of direct worker control and/or ownership of industries as a model for transforming the relations between capital and labor as opposed to state centered socialist models, (2) anti-centralization, expressed through rank and file control within unions and organizational autonomy within larger federations, (3) the establishment of One Big Union inclusive of race, gender and skill through which labor extracts greater control over the workplace and concessions from employers, (4) direct action as the primary social change approach with the general strike viewed as labor's most powerful weapon, (5) a rhetoric of class conflict, with class broadly defined as including all people who labor in the workplace as opposed to those who don't.

The workplace collectivism prevalent among organized labor in Seattle was produced by a number of influences. The first was the cultural legacy of communitarian socialists who migrated to this region in the late nineteenth century. Many of the participants were inspired by the millenarianist ideas of Edward Bellamy, among others. In 1887 the Puget Sound Cooperative Colony provided the economic infrastructure for what would become the future town of Port Angeles.

In 1896, a group calling themselves the "True Populists" committed themselves to practically applying their socialist principles. The new organization titled the Brotherhood of the Cooperative Commonwealth vowed to concentrate colonies and industries in one state until it was socialist. Eugene Debs was the national organizer in1887. He proposed a migration of socialists to some Western states. As Washington already had a number of communitarian settlements, the BCC vowed to make Washington the first socialist state in America (Dembo, 1978, 27). The migration attracted urban and rural workers from the East. As a result of the colonization a socialist press emerged. A number of general strike participants had been admirers of the BCC.

The second and third influences had to do with the impact of the Knights of Labor in the late nineteenth century and the Industrial Workers of the World (IWW) in the early twentieth century. The Knights of Labor built upon the legacy of the cooperative movements of the eighteen forties and sixties. They sought to abolish the wage system and replace it with an industrial system consisting of cooperative institutions for both production and distribution. "Consumer cooperatives were but a stepping stone to producers self employment. Eventually when the order had grown to include nearly all useful members of society ... it would control practically the whole market" (Perlman, 1923, 72). Checks would be placed upon the accumulation of wealth, and small scale enterprise maintained, through changing the legal system from privileging property owners to creating a legal equality between capital and labor. The cooperative commonwealth was an alternative to the process of industrialization and capitalist concentration in the late nineteenth century that was hurting the "producing" classes, those who labored directly in the workplace rather than absentee owners or stock holders. The producing classes included workers, artisans, small business owners and farmers.

The Knights stated goal of creating a cooperative commonwealth, their belief in the labor theory of value and the rights of "producers," can be traced to the radical Republican tradition and its reconstruction by early unionists during the Jacksonian era. Although the Knights did support a role for the state through ownership of telegraph and railroad industries, the primary economy was to consist of worker owned cooperatives for production and distribution.

The organizational structure of the Knights, which included both skilled and unskilled laborers, women, and people of different races, was an innovation. In practice, however, the Knights were not as inclusive as they claimed. Most of the local assemblies discriminated against women and people of color. Yet the Knights did succeed in establishing a national 
membership of roughly one tenth women and one tenth African Americans (Voss, 1993, 81). Their motto reflecting this inclusive strategy was "An Injury to One is the Concern of All."

The Knights of Labor had grown rapidly in Tacoma and Seattle after 1885. In a time when there were few free libraries, the Knights provided reading rooms in Seattle, Tacoma, and Spokane. These rooms made literature such as Laurence Gronlund's Cooperative Commonwealth. Edward Bellamy's Looking Backward, and the Knight's labor journals available to the average worker (Schwantes,1979, 25). But they went into decline in Seattle by the turn of the century. Their demise might have resulted in the flourishing American Federation of Labor (AFL) craft unionism had it not been for the foothold established by radical industrial unionists in what were to become two key industries in the state of Washington -- lumber and mining. Workers in these industries were organized from their inception by the American Labor Union (ALU), an offshoot of the Western Federation of Miners (WFM), some of whose leaders eventually founded the IWW. The WFM had close links to the Knights of Labor in the Pacific Northwest. When the organization dissolved by 1902 the WFM became populated with "thousands" of former Knights (Schwantes, 1979, 30).

The most famous anarcho-syndicalists in U.S. history were the IWW. Their organization, strategy and goals differed considerably from state-centered socialist or communist models. Rather, they were anti-statist and sought direct control over industries by the workers themselves. The IWW eschewed reformism through the electoral process in favor of direct action. The general strike was the tactical means by which control of industry could be transferred directly to the workers while undermining the need for a bureaucratic state. The IWW's anti-statist doctrine and reliance on the general strike as a vehicle for revolutionary social change was influenced by anarchism $\mathrm{B}$ and revolutionary sydicalism that had emerged in Europe at the turn of the century. Anarcho-syndicalism retained some of the presumptions of the anarchists while adopting the trade unions for its organizational base and militant direct action as its tactics. While rejecting Marx's emphasis on the state, anarcho-syndicalists did incorporate the doctrine of class struggle.

The IWW represented a specifically American hybrid of anarcho-syndicalism. Author John Brooks recalled how he overheard a journalist asking an IWW member how to learn about their history. "Study the Knights of Labor first, most of it is there," came the reply (Brooks, $1913,64)$. The commonalties among the Knights of Labor and the IWW have been noted by a number of scholars. The most significant similarities was their desire for a worker owned and managed economy, and their organizational promotion of One Big Union which included the unskilled, women and racial minorities. The similarity of the Knights of Labor motto "An

\footnotetext{
${ }^{3}$ Anarchism teaches that economic and social injustices are intimately linked with the centralized organization of the state which inevitably produces hierarchy and oppression. The doctrine proposes a social organization of localized, autonomous communities freely interacting through mutual cooperation. See Proudhon (1966), Kropotkin, (1987) and Bakunin, (1970).

${ }^{4}$ Revolutionary syndicalists had been influenced by the philosophy of Bergson and Nietzsche, both part of the antirationalist backlash prominent in late nineteenth century Europe. The emphasis on paralogical influences in human behavior and the celebration of emotion, intuition and instinct in opposition to empiricism and reason are apparent. See Georges Sorel's Reflections on Violence.

${ }^{5}$ Despite the IWW's masculinist rhetoric and imagery, radical industrial unionism necessitated that women workers, often immigrants, be organized. Bill Haywood, a legendary IWW leader, even proposed organizing children who were working in factories.
} 
Injury to One js the Concern of All" and the IWW motto "An Injury to One is an Injury to All" is self-evident. 6

The city of Seattle became a stronghold for the IWW in the early twentieth century, but there were also strong "wobbly" tendencies among maritime workers along the West Coast down to San Francisco. This was no coincidence. Political culture was communicated through interactions among loggers and sailors whose political orientation had been influenced by the IWW and other labor radicals in the Puget Sound region, with longshore workers. These interactions were mediated through social and occupational networks created through the interchange of jobs in the early twentieth century. Kimeldorf describes this interchange:

In the early days of the lumber industry, trees felled by loggers were floated downstream to the docks where longshoremen loaded them aboard steam schooners for seamen to lash in place on the deck. With this vertical integration, occupational boundaries became very fluid; many men actually followed the movement of logs from forest to dock to ship and back again.... Constant shuffling and reshuffling of work crews, whether aboard ship or in logging camps, generated a dense network of social contacts, exposing both groups to a correspondingly wide range of ideas. This was especially true of seamen, arguably the most cosmopolitan body of workers in the world. Their greatly expanded opportunity for communication with other people and their frequent contact with foreign cultures familiarized them with the breadth of socially structured inequality (Kimeldorf, 1988, 24, 20).

Notably, a workplace collectivist orientation was evident in the longshoremen's strike after World War One. In addition to wage increases, they went out for a share of ownership, profits and directorates of the employing companies (Chiles, 1981, 17).

Nelson points out the syndicalist orientation among the Australian Seamens' Unions as a contributing influence on West Coast sailors. There was a significant overlap in the membership books of West Coast and Australian unions (Nelson, 1990, 65, 66). The syndicalist influence among sailors, while having an appeal to certain categories of American workers, was also international in character, and this created another occupational network through which they became syndicalist variants. The Australian seamen had adopted some principles and tactics of the IWW but did not have large numbers of seamen who were members. In fact, Harry Bridges, who was instrumental to the emergence of the San Francisco general strike, was Australian, and formerly a sailor who had been a member of the IWW for a short time. Nelson explains that "Although this movement was largely independent of the moribund IWW, it reflected the mood of syndicalism that was so widespread at this historical moment."

This diffusion of syndicalism from the Pacific Northwest through occupational networks in the first two decades of the twentieth century left its mark on the 1934 coast wide maritime strike and the San Francisco general strike. Toby Christensen worked in the woods before becoming a longshoreman, and Jack Mowery was a maritime worker. In an interview they described how their membership in the IWW influenced tactics during the1934 maritime strike:

\footnotetext{
${ }^{6}$ There were, of course, distinctions. Most significant was the centralized organization of the Knights of Labor and their use of the political system in attempts to change the state. Voss has pointed out, however, that while the Knights were a centralized organization on paper, in practice there was much autonomy among the local assemblies (Voss, 1993, 76, 77).
} 
[We learned how] to conduct a strike. Figure out how the employer was going to do. Try to outmaneuver him, and get things on your side instead of letting him go in and get a head start on you and so forth...we outguessed the employer when we decided to strike there wouldn't be no scabbing on the Portland waterdocks. And we set up our picket committees with certain picket captains. They knew they was going to have control over those pickets, and knew if they had guts enough to stop the scabs if they started in to the waterfront. I think that was the main point right there (Egan, 1975, 72).

As we shall see, the unionists did "outmaneuver" the employers in 1934, but not so in 1919.

\section{CASES}

In order to analyze divergent outcomes, we must first look at the configurations of social processes from which the outcomes emerged. The Seattle case will be presented first, followed by the San Francisco case.

\section{The Seattle General Strike}

In 1916 the American government took action to stimulate the shipbuilding industry through an act of Congress. Federal government assistance was to be provided for the establishment of a United States Shipping Board, which was formed in 1917. While the Board retained a supervisory function over all shipyard construction, the government agency responsible for the promotion of construction was the Emergency Fleet Corporation, which was also established in 1917. The U.S. government neither owned nor operated the shipyards. This was done by private interests through government funds to create shipyards and to purchase ships.

During W.W.I. the federal government prohibited employer discrimination against union shipyard employees. The shipyards became almost $100 \%$ unionized. The dramatic increase in union density due to war preparation afforded an organizational basis for much more effective strikes, including general strikes. Labor also gained a new position of power due to the need for increased and uninterrupted production of war materials. As resources increased for unionists, workplace collectivist political culture flourished through the proliferation of social movements, and alternative institutions such as workers' cooperatives and union owned enterprises. The first cooperative in Seattle was incorporated in 1915. The"Mutual Laundry" was formed to support laundry workers threatened with being blacklisted and to keep worker's dollars in their own hands. Soon other labor cooperatives were formed including various stores, a bank, and the Labor Temple Association, with a fund of up to $\$ 75,000$ contributed by roughly sixty of the local unions (O'Connell,1964, 5). The Boilermakers invested in a labor owned food store. The Seattle Central Labor Council organized a "Workers' College," and the first daily labor newspaper in the country was established -- the Seattle Union Record. It served as a vehicle for the communication of workplace collectivist principles, cartoons, poetry and current information on international revolt and worker's struggles, especially post-revolutionary developments in Russia. Worker's demonstrations and mass rallies often drew thousands.

Numerous historians, including Freidheim, who describes it as follows, have recognized the radical political culture among Seattle unionists:

The Seattle AFL movement was more radical than most other American city-wide movements. While other cities had radical fringes, in Seattle there was wide consensus on radical solutions to the question of labor's place in society...[T]he idea of class 
consciousness was implicitly accepted. Seattle labor looked at itself as a class apart denied its birthright. The prevalent feeling was that workingmen had a natural feeling toward each other as class brothers. The corollary to class consciousness was class conflict -- if some were brothers, others were natural enemies. While in actuality Seattle labor did not treat all employers as irrevocable enemies, and in fact prized some nonlabor liberals and farmers as friends and allies, still the jargon of class conflict was in constant use (Friedheim,1964a, 24).

Within this political culture both the moderates and the radicals represented different strands of workplace collectivist political traditions. But regardless of where a worker fit on the political spectrum, the dominant orientation exhibited workplace collectivist characteristics, especially the principle of direct worker ownership and/or control of the industries. Harry Ault, the editor of the Seattle Union Record, stated that the idea of "labor ownership of industry" was widely agreed upon.

I believe that $95 \%$ of us agree that the workers should control the industries. Nearly all of us agree on that but very strenuously disagree on the method. Some of us think we can get it through the Cooperative movement, some of us think though political action, and others think through industrial action ...(Freidheim, 1964b, 148).

While W.W.I. war related production contributed to the resources, power and the cultural production of Seattle workers, unions were also limited by contractual obligations made by national AFL officials such as the no strike pledge. Many Seattle unionists did not agree with this pledge. The workplace collectivists and socialists favored local rank and file decision making through referendums. Since the rank and file did not vote on this agreement, they felt that unionists should not be held accountable to it. There was also a good deal of suspicion about the agreement due to a prevalent attitude that distrusted authority, the employers, and the state in particular.

Several months prior to the end of W.W.I., the Shipbuilding Labor Adjustment Board (SLAB), a state appointed board that settled wage disputes, engaged in wage adjustment to catch up with the increasing cost of living. Shortly after the war ended, the SLAB board announced its decision. Most shipyard industries received a retroactive increase except in the Puget Sound district where some occupational categories actually received a wage reduction. For example, skilled metal trades workers received an increase whereas less skilled workers received a decrease. The state justified this action by claiming that it was attempting to create a more uniform industry-wide wage standard.

Contracts, which lowered the wages of unskilled workers while raising them for the skilled, had been accepted around the country where AFL craft unionism prevailed. But due to the workplace collectivist principles of Seattle workers, specifically their support for One Big Union, the contract was rejected as an attempt to divide them and negotiations continued. When it began to look like some of the employers were going to sign new contracts, Piez, the head of the federal Emergency Fleet Corporation (EFC), sent a telegfam to the employers stating that if they gave in to the unionists they would lose their contracts. ${ }_{\text {But rather than having the telegram }}$

\footnotetext{
$7 \quad$ The reason that Piez would go this far was subject to speculation. Friedheim (1964a) described three possible scenarios proposed by different labor sources. The first was that the local employers sincerely wanted to come to an agreement with labor. Both parties resented Piez's control over the shipbuilding industry. So employers
} 
delivered to the Metal Trades Association, the employers, it was accidentally delivered to the Metal Trades Council, the unionists. Infuriated, the metal trades unions soon went on strike.

A metal trades strike began on January 21, 1919. Piez of the EFC remained intransigent about not increasing wages. Shortly thereafter the Seattle Central Labor Council had a meeting. Its leaders, however, had gone to Chicagg for a national labor convention dedicated to freeing imprisoned labor activist Tom Mooney. While the Labor Council officials were out of town, the Metal Trades representatives proposed a resolution for a referendum on a general strike in support of the Metal Trades workers. At the Central Labor Council meeting, the balconies were packed with IWW members prodding the metal trades workers on. The council delegates enthusiastically approved a resolution supporting a general strike. The labor leaders returned to find that numerous unions had already passed the referendum.

A wide variety of unions voted in favor of the general strike including the Milk Wagon Drivers, the Musicians, the Teamsters, the Plumbers, the Hotel Maids, the Longshoremen, the Housepainters and Decorators, and the Typographers. A number of the unions voted unanimously: the electricians, "lady barbers," and cigar makers were only three examples. Initially, the only opposition to the strike came from the Gas Workers, and the Federal Employees Union, whose officers stated in a letter that their delegates were instructed to vote with the conservative members of the Council and to oppose "that radical element seeking to tear down and destroy what the Ceptral Labor Council and the American Federation of Labor had been 20 years in building up." 9 Morgan noted that one hundred and ten unions in all voted to strike including the carpenters, perhaps the most conservative union in Seattle. Due to racist restrictions, Japanese unions could not have representatives on the Central Labor Council but despite this, they sent two delegates to tell the Council that they would also strike (Morgan, 1951, 201). They were admitted to the unions in a participatory but non-voting role (Berner, 1991, 289).

Prior to the first general strike meeting, the representatives of the Central Labor Council decided that the strike would be a "sympathetic" one and not a "mass" strike, which some representatives argued for. The latter type of strike implied that all unions would list grievances and stay out until they were met. The Council opted for an emphasis on solidarity, the unionists showing support and sacrifice for other workers. The general strike began on February 6, 1919.

Xenophobic sentiments and polarization during the war provided the mechanisms for containing the threat of organized labor. At the same time that war production and participation enabled a workplace collectivist political culture to flourish in Seattle, it also contributed to a hyper-patriotism among state actors, conservative organizations, and much of the public, the

and workers were actually working together to undermine Piez. The strike had been approved by the shipowners,in particular Skinner and Eddy. Harry Ault, editor of the Seattle Union Record firmly believed this to be the case.

The second possible explanation was that Piez was forced to take a firm stand on the Macy award due to the pressure from Seattle shipyard management, who could not absorb the cost of wage increases. Apparently, the pressure was mostly from the smaller yards. This version was proposed by William Short of the Washington State Federation of Labor.

The third possible scenario proposed that Charles Piez was trying to crush Seattle unions so he could protect his investment in a shipyard in his native Philadelphia. The shipyard owners went along with this because "Eastern capitalists" had bribed them with stock in the eastern shipyards. This version was most popular among the rank and file. Freidheim maintained that the last version had the least evidence to support it while the second version had the most credibility.

8 Tom Mooney had been framed for bombing a parade in San Francisco in 1916.

9 Seattle Union Record, January 30, 1919, 1. 
latter of which was exacerbated by the successful Bolshevik revolution only two years earlier. This political climate during W.W.I. legitimated an all out attack on labor radicals. During the war the government developed an unprecedented surveillance apparatus to identify "dissidents." The Espionage Act was passed in 1918 to provide a legal basis for suppression of those actively opposing the war. "Patriots" like the Minutemen in Seattle organized voluntary units to assist the government in their efforts to track down anti-war "reds." Different means were used to target "radicals," from government sweeps of IWW camps in the woods, to criminal syndicalist laws or indiscriminate arrests for "vagrancy" or "profanity," along with brutal vigilante attacks like the ones in Everett, Washington in 1916. Such actions presaged the Palmer's Raids of the 1920s when numerous unions were pressured to rid their ranks of radicals. Although the prime target of the state and their voluntary watchdogs was the IWW, the more moderate Seattle Central Labor Council had been subject to criticism for its open opposition to the war. Along with the media, politicians, and employers had license to vilify any union efforts toward progressive change as "un-American."

By the end of the war, the social climate in Seattle had changed. This was evidenced by the shift in popular perceptions of political categories. Prior to the war, the political spectrum had been characterized through the categories of "interests" (a pejorative term for big capitalists) versus the "progressives" (coalitions among middle class reformers, organized labor and farmers), to the post-war categories of "patriots" versus the "reds." During the general strike former allies were unwilling to take a stand in defense of strikers who had been branded as "Bolsheviki" and accused of promoting a "revolution in Seattle." The economy exhibited high levels of unemployment and job insecurity related to W.W.I. demobilization. The non-union public had little sympathy for "alien" agitators nor did they easily relate to the complaints of industrial laborers who made some of the highest wages in the country.

As the general strike progressed, political alliances and divisions that would be crucial to its outcome formed. When the community first heard about the EFC ruling that reduced the wages of unskilled workers, many middle class progressives, religious leaders, and even some business leaders thought it unfair. They initially supported the strike on the behalf of unskilled workers. But once the referendum for a general strike was passed sentiment changed. During and after the strike, employers, most of the city's newspapers, and city, state and federal officials, strongly condemned it as the work of radicals who needed to be contained.

The media, employers and state officials were joined in their condemnation of the general strike by state and federal AFL officials. But not by officials in the Seattle Central Labor Council. The General Strike Committee and Committee of Fifteen who directed the strike were both elected by the rank and file. Through negotiations, General Strike Committee representatives proposed resolutions that would limit the general strike or try to end it. The rank and file rejected most of these. The termination of the general strike in Seattle occurred not because it was cut off but because it had no place to go. The goal was to show solidarity with the metal trade workers but it was not clear whether or not the general strike would continue until concessions were won. The general strike lasted roughly five days when the General Strike Committee called it off. While exhibiting an outstanding degree of solidarity among working people, it did not win concessions for the metal trades workers who eventually lost their strike.

In Seattle state actions were repressive. The federal government sent in the army in case the "revolution in Seattle" got out of hand. Knowing that their opposition wanted them to "start

\footnotetext{
10 According to the IWW's newsletter, the Industrial Worker, the strike could not have succeeded because its goals were not revolutionary. It was a demonstration strike, but the state was in a better position to wait it out.
} 
something," unionists were nonviolent. This response was made easier by the fact that strike breakers were not brought in during the strike. A labor police force composed of veterans patrolled the streets to see that crowds did not gather. The IWW promised not to start anything. Despite the peaceful nature of the general strike, "alien" radicals were deported and the offices of socialists and IWW members were closed down.

Although President Wilson was a progressive era Democrat who courted the labor vote, he had publicly committed himself to fighting Bolshevism. The socialism of the progressive era, which was embraced by a number of "respectable" people, was differentiated from the radicalism of the Communists or of the IWW. The Wilson administration supported a corporate liberal model of industrial relations, especially Secretary of Labor Wilson, a former union activist. Administration officials thereby framed moderate AFL trade unionists as the "responsible" workers versus the "radicals" whom were the source of the trouble. Top officials in his administration contributed to the public discourse, which characterized the Seattle general strike as a threat to Americanism.

But something more was going on here. Organized labor had made the greatest economic and political gains in history during W.W.I. This was due to increased employment due to war production and to the corporate liberal policies implemented by the state to ensure uninterrupted production. After the war was over we see a concerted effort by organized employers and state officials to put the genie back into the bottle, so to speak, to undue the gains that labor had made which were perceived as a post-war economic threat to employers. Consequently, the American Plan was hailed by the employers, the press and numerous politicians as an alternative to closed shop unionism. The labor radicalism that flourished during the war years constituted a political threat to capitalism. It was dealt with by drawing upgn the repressive state laws and the surveillance apparatus that emerged during the war.

Seattle experienced the post-war depression and closing of its government subsidized industries a year sooner than other West Coast ports. This was due both to Piez of the EFC making good on his threats to withdraw contracts to punish unionists for the general strike and to inevitable post-war decreases in shipbuilding. The loss of jobs in manufacturing in Seattle dropped from 40,853 in 1919 to 13,699 in 1921, a decrease of $66 \%$ compared to the average decrease of $22 \%$ in sixty-eight surveyed localities (Rosenthal, 1992, 53, fn 36). As a result, union density decreased and the composition of the workforce changed. Most radical workers who had been drawn to the shipbuilding industries left Seattle to find jobs elsewhere. Many of the workers' enterprises, some labor owned cooperatives which formed during the war production years and some which formed shortly after the general strike went under due to the decrease in resources and radical labor activists dedicated to their success.

The depression, which eventually hit all port cities, led a number of workers to blame the general strike. Some of the more moderate unions disaffiliated with the SCLC. The dynamics of the previous balance among conservatives and radicals that had been maintained by the moderates changed, with the progressives and moderates now in direct conflict. The loss of economic resources, changes in workplace composition, and conflicts within the SCLC resulted in the demise of workplace collectivist political culture, which flourished during the war production years and shortly thereafter.

11 A similar process occurred after W.W.II. Toward the end of the war and through 1946 more anti-labor legislation was passed than at any other time during U.S. history. This culminated in the Taft-Hartly Act in 1947, which outlawed sympathy strikes, among other restrictions. Notably, the last American general strikes occurred in 1946. 
The general strike had demonstrated massive union solidarity envisioned by workplace collectivists. The feeling was that the time was ripe to push for a break with the AFL and to create a West Coast Federated Union. Tactically, this could be accomplished if they were successful in having the entire pacific coast brake away in one move so that the Internationals could not interfere. The push for Federated unions was a direct threat to the Seattle Central Labor Council who supported remaining affiliated with the AFL. A vote was forthcoming. The national AFL threatened to revoke the Washington State Federation's charter if it passed. The resolution lost 95 in favor to 57 against it (Berner, 1991, 300). While the Federated Union movement lost, the Seattle Central Labor Council still supported the principle of One Big Union. A resolution was passed to propose a form of industrial unionism to the national AFL

One last post-strike development involved the claim of "Long time radical maverick John Becketson." He stated that the groundwork for the Maritime Association organized in 1921 was built during the shipyard strike and the Seattle general strike. It achieved a form of industrial unionism on the waterfront by organizing the maritime union coast wide into One Big Union. As we shall see in the San Francisco case, this association wasn't the only legacy that workplace collectivism left to the maritime workers on the West Coast.

\section{The San Francisco General Strike}

The second general strike took place in San Francisco, California in 1934. The patriotic fervor in which the Seattle general strike was enveloped was a world apart from the political climate of the Great Depression. The legitimacy of the capitalist economic system was in question due to its worldwide failure. ${ }^{2}$ By the early 1930 s over one million farmers had lost their farms. By 1932 roughly seventeen million people were unemployed. Many workers were fired, laid off, had their wages cut back or were subjected to increases in production through speed-ups. These changes often made working conditions even more miserable and dangerous then they were to begin with. The status of longshoremen on the West Coast was comparable to that of contemporary agricultural workers -- grossly underpaid, no job security and minimal workplace protections. In the parlance of the time, they were "wharf rats." Jobs were obtained on a daily basis through what was called the "shape up." Those interested in working would gather in a circle while an agent of the employers selected from the crowd those who worked that day. The longshoremen belonged to the "Blue Book," a closed shop company union. Anyone attempting to organize another union was blacklisted. The "shape up" led to extreme corruption in the form of favoritism and manipulation of workers.

Due to impact of the depression and the Hoover administration's refusal to seriously confront it, there was a proliferation of radical social movement organizations. Membership in the Communist Party (CP) grew, as did other organizations that they founded -- International Labor Defense (ILD), International Workers Relief (IWR) and various unemployed councils which sprouted up around the country. Although there was police repression of these groups, employers and big capitalists had a more difficult time framing themselves as patriots while scapegoating "radicals" as the cause of social ills. It was in this social and economic climate that Franklin Roosevelt, with his campaign promises of a New Deal, was elected in 1932.

The CP experienced a resurgence and was very active in San Francisco. They concentrated on distributing their newsletter, the Western Worker, and organizing numerous forums, meetings, demonstrations and classes. Labor schools offered night classes on Marxian economics, principles of Communism and the History of the American Labor Movement

\footnotetext{
12 Communism gained greater credibility at this time because Soviet Union, less dependent on the world capitalist economy, was not as hard hit during the depression.
} 
The communist Marine Workers Industrial Union (MWIU) attempted a campaign on the docks in 1931 which was ineffective. Harry Bridges, a future leader of the general strike, assessed its failure as follows:

They didn't catch on at all because... their program was pretty revolutionary, pretty idealistic...despite the fact that the people felt pretty desperate, they didn't cotton too much to their...political views (Chiles, 1981, 81, fn 40.)

In December of 1932 the Waterfront Worker began publication. The first newsletter was printed in the rented room of a MWIU member, although the Albion Hall group produced it. This group consisted of a small number of syndicalist oriented longshoremen and communist members, known by the name of their meeting place in the Mission District, Albion Hall. According to Mitch Slopodek, there was already restlessness on the waterfront "but no direction. The paper gave one." ${ }^{13}$ It was a mimeographed newsletter written anonymously by "Rank and File stevedores" to avoid repercussions from the employers. Even letters to the editor were signed by a "rank and file stevedore" or a "stevedore's wife." The newsletter was circulated quietly, person to person, by the dockworkers. It communicated the resentment the longshoremen felt over working conditions and the Blue Book union and argued for the formation of a new union run by the "rank \& file."

Part of the reason that the MWIU's early mobilization appeals did not resonate with the dock workers, according to CP member Sam Darcy, was that the communists didn't have one worker on the docks. Since they were on the "outside" the creation of the Albion Hall group, which published the Waterfront Worker with rank and file longshoremen, was to their advantage. But to maintain a relationship with longshoremen compromises had to be made, Darcy explained:

In the group which published the Waterfront Worker, were included a minority of Communists, and other militant elements. The guiding line for this group was above all to develop a militant group of workers united with the objective of breaking the Blue Book union and to establish a real union. At times there was criticism that the Waterfront Worker did not take a clearly enough militant stand on this policy or that policy. When this criticism was justified, it could in every instance be traced to the desire of the Communist elements in the group not to sacrifice the unity of the militant elements for a clearer formulation on the minor questions. In other words, the group felt it was more important to attain the larger objective of developing a united militant group (not limited to Communists alone) than to refuse to make concessions to this or that backward idea amongst the workers (Darcy, 1934, 65).

Nelson has pointed out that the Waterfront Worker, although having members from the MWIU was not a publication that represented that organization (Nelson, 1990, 12). He responds to charges that communists in the1930s led labor militants by arguing that it overlooks the fact that Pacific Coast maritime workers had developed a militant subculture over the previous fifty years. They had periodically called for "cooperating federations" and "One Big Union." It is significant for the practice of workplace collectivists principles, and the success of the future

13 Larrowe,Charles, Harry Bridges: The Rise and Fall of Radical Labor in the United States, 1972:13 
coast wide strike, that when the Pacific Coast district rejoined the ILA in 1911, the coast locals were granted complete autonomy.

In the summer of 1933, the National Industrial Recovery Act was passed. To the longshoremen, Section 7a of this act legitimated the right of workers to collective bargaining through a union of their choice. Shortly after this Act was passed the longshoremen in San Francisco got a charter to affiliate with the International Longshoremen's Association (ILA) of the AFL. Hundreds of them gathered in San Francisco, created a large bon fire and burned their "blue books" representing the company union which dominated the waterfront since the 1920s. ILA membership increased rapidly along the coast especially after the S.F. Labor Relations Board ruled that the Matson Lines, which had fired four longshoremen for wearing ILA buttons, should reinstate them and recognize the new union employees. The employers, however, still refused to recognize the ILA.

Before long workplace collectivist and moderate factions were at odds with each other for control of the new union. The workplace collectivists, whose most prominent spokesperson was Harry Bridges, called for a coast wide rank and file convention to decide on strategy and goals. Rank and file unionists organized a coast wide convention. The delegates represented 14,000 longshoremen elected by their co-workers from various West Coast ports including San Francisco, Oakland, Stockton, San Pedro, San Diego, Seattle, Tacoma, Portland among others. Both employers and the AFL officials argued that a convention should be postponed until a new Shipping Code was written. But again, the workplace collectivists direct action rather than relying on the state or the AFL "buro-crats" to look out for their interests. Rank and file control was prioritized to such a degree that a motion passed to deny AFL officers status as delegates. Ryan sent a telegram to the rank and file convention, stating that he was having problems getting the ship owners to meet with him because of the "radical leaders" in control of the ILA on the Pacific Coast. He suggested that if the majority of ports wanted to sign an agreement then let them do so and leave the radical ports to fend for themselves. The delegates at the convention responded to Ryan with a resolution declaring that all of the locals were loyal to the AFL, but they did not follow his suggestion.

At the convention, ILA officials cautioned that in the long run the longshoremen would be better off to wait for the establishment of a shipping code for the maritime industries. Section 7B of the National Industrial Recovery Act had authorized industries to prepare operational codes to help to stimulate the economy and mitigate the economic distress of working people. But Bridges pushed for direct action. The moderate faction succeeded in gaining control over the leadership of the new union by having their people elected on the Executive Board. But the workplace collectivists succeeded in pushing through a number of proposals that were adopted. This included calling for coast wide contracts, pay raises, a thirty hour week, the formation of a waterfront federation, unemployment insurance, and a resolution against ships flying the Nazi flag, and a union controlled hiring hall (Darcy, 1934). The only way favoritism could be stopped and job security provided was if the union rather than the employers dispatched workers. But the legitimation for this demand, not recognized by AFL officials on the East Coast, was the workplace collectivist principle proposing that it "is every American's right to organize and control the job." A belief communicated by an ILA representative over the radio during the general strike (to be discussed shortly).

The delegates took their demands to the employers but were rebuffed as "communists" and told that the employers would only talk with "responsible" labor leaders, meaning moderate AFL officials. A strike vote passed for a coast wide strike of longshoremen to begin in March 1934 but President Roosevelt asked for a postponement. He appointed a board to mediate the 
dispute. Various agreements were proposed by the mediation board, the employers, and AFL officials, all of whom did not recognize the demands of the rank and file convention. On May 9 the coast wide strike began. The blockage of most West Coast ports constituted a serious economic threat to the employers.

The moderate longshoremen faction called in Joseph Ryan, President of the ILA, to take control of the situation. He arrived in May from the East Coast. From the time he stepped off the plane announcements were made to the press and agreements with employers without consulting the rank and file. He was respected by a good number of the longshoremen due to his position as the president of the ILA. But fundamental differences in political orientation were apparent in Ryan's idea of what a union was and the place of the rank and file in it. He had publicly defended the shape-up as a method of hiring, and was a strong supporter of craft unionism, believing that contracts should be negotiated separately in each port. Ryan initially offered to give up the closed shop demand in exchange for union recognition. But the rank and file rejected this offer through a statement made by Bridges that put him publicly at odds with Ryan. Bridges declared that "Settlement for mere recognition may mean a lot to national heads of the International Longshoreman's Association who get fat salaries. But the workers are going to hold out for nothing less than a closed shop" (Larrowe, 1972, 49). A challenge to the practices of the AFL hierarchy had been coalescing. It manifested itself in the contest between Ryan, and other AFL officials, state representatives, the police and the employers, who did things the old way, and the workplace collectivists trying to move unionism in a more rank and file, industrial unionist direction. The latter consisted of rank and file longshoremen and some Communist Party members who printed the newsletter the Waterfront Worker, a few CP organizations, and a growing mass of unionists who believed they had a right to a greater control over their unions, their workplace, and their lives. Increasingly Bridges was recognized as the one with the strategic skill to take the union in the new direction.

After negotiations to end the strike were attempted but failed. A meeting was then held with the mayor of San Francisco, representatives of the Industrial Association, the Chamber of Commerce and the police. They made plans to "open the port" with the use of the police. Quinn points out that as early as May 13 thirty industrial heads met to discuss the prospects for "opening the port." Another such meeting of about sixty prominent business leaders was held on May 21. An action committee with seven members was elected. They in turn opened communications with representatives of shipping interests in all ports, and state officials Dean Henry Francis Grady and Assistant Secretary of Labor McGrady. On June 15 the Industrial Association of San Francisco sent a telegram to President Roosevelt warning that "industrial conflict of a character too serious to contemplate" would result from their attempt to move cargo and that a solution had to be found. Roosevelt neither acknowledged nor replied to this telegram. A telegram was also sent to Secretary of Labor Francis Perkins asking her to intervene. She did not acknowledge or respond to the telegram from the Industrial Association (Eliel, 1934, 63). Soon after this, the Mayor of Seattle announced that he was taking control of the police forces and appointed additional deputies. The mayor of Portland took similar action.

After the defeat of the June 16 agreement there was increased agitation for a general strike. William Dunne, writing from a communist perspective, maintains that the MWIU affiliated with the Trade Union Unity League, first promoted the staging of a general strike. The Joint Strike Committee of the Waterfront Unions, led by Bridges, endorsed the proposal but the San Francisco and Oakland Central Labor Councils opposed the idea. Bridges and the Joint Marine Strike Committee then took the proposal directly to the rank and file in which the vast majority of the unions voted in support of having one. Quinn and Eliel stated that about mid-June 
the International Association of Machinists began sending out a General Strike Call to other unions. Both also mention that about this time, the Women's Auxiliary for the International Longshoremen's Association began distributing a series of handbills declaring the sentiment "Forward to a General Strike." In addition Eliel mentioned that when the machinists were voting on the general strike proposal on June 20, the Oakland Teamsters had already taken a vote on June 19. At this time the waiters, window washers and bookbinders were preparing to take a similar vote (Eliel, 1934, 79). Yet, the idea of a general strike had been proposed in the Waterfront Worker as early as May 1934.

The San Francisco Labor Council had been adamantly against a general strike and passed an anti-Communist resolution reiterating the views of Ryan and the employers that communists had taken over the waterfront. Bridges, and some other delegates, opposed the resolution but they were in the minority. At a meeting of the San Francisco Labor Council on June 29 a number of delegates proposed having a general strike. There was not a strong reaction of support among the representatives. The Teamster officials were clearly opposed. The workplace collectivists knew that if a general strike were to take place it would not be through the medium of the San Francisco Labor Council.

By mid-June the employers and the longshoremen had rejected tentative contracts and were still determined to maintain their positions. Rumors were beginning to spead that the industrial association was going to "open the port" by force and that the unions would respond with a general strike. Mayor Rossi made a last effort to settle the dispute. He called Ryan back to San Francisco where on June 15 they spent the day at a secret meeting with Plant who represented the Waterfront Employer's Union representing employers from San Francisco, Los Angeles, Portland and Seattle. Once again, Ryan did not consult the rank and file about the details of a new agreement. After the Industrial Association had approved the document, a meeting was held in the Mayor's office the next day. In attendance were Ryan, John F. Forbes, president of the Industrial Association with two other members, Mayor Rossi, the members of the president's mediation board, William Lewis, president of the Pacific Coast District ILA, A.H. Peterson and J.J. Finnegan of the ILA Executive Committee, Michael Casey, John P.

McLaughlin, and Dave Beck of the Seattle Teamsters. McGrady was not at this meeting nor was Bridges. All were aware that the rank and file had voted to have contract propositions voted on prior to approval (Quinn, 1949, 83).

The new agreement differed little from the May 28 deal that had been rejected by the entire West Coast rank and file. It proposed joint control of the hiring halls, a separate contract for the longshoremen without regard to the other striking maritime workers and wages and hours decided through arbitration. Except this agreement included two significant clauses. First was a sanction against sympathy strikes. The second clause stated that "We guarantee the observance of this agreement by the International Longshoremen's Association membership" (Bernstein, 1970, 270). The agreement was signed in Rossi's office on June 16. Casey also committed the Teamsters to return to work even if the longshoremen didn't accept this agreement. Work would begin again on June 18.

There was a meeting of several thousand rank and file longshoremen on June 17. Bridges had publicly stated that if the agreement received two-thirds vote of approval for the entire Pacific Coast, the longshoremen would go back to work. Ryan was late and by the time he got there the agreement had been subjected to much criticism. He was unable to speak without being subjected to insults from the audience. Bridges confronted him about not consulting the rank and file. By unanimous vote, the rank and file took the power to negotiate out of the hands of the 
AFL officials and elected a Joint Marine Strike Committee to conduct negotiations. It had five representatives from each union and Harry Bridges was nominated its chairperson.

On June 18, Ryan met with the others who had signed the contract in the Mayor's office and told them that the union had been taken over by communists and was "out of control." The agreement was rejected at almost all of the ports. The rank and file Teamsters refused the agreement as well. Casey, the Teamsters San Francisco president, was "shaken" and stated that sending Teamsters to the waterfront would result in "confusion and possibly worse"(Bernstein, 1970, 271).

On June 17, the chairman of the ILA publicity committee made a statement to the press that reaffirmed the principle of rank and fileism:

The public should understand that it is not the officials that are on strike, and it is not the officials that would have to go back to work under these so-called agreements. The officials say that this is the best agreement that they could get -- and that it was pretty fair. The men themselves, after studying the agreement, found it to not be an agreement between employer and employee but, merely an employer's agreement...

It should be understood that the longshoremen have broken no agreement as no agreement was ever entered into by the longshoremen and employers. International President Ryan had no power to sign any agreement, but merely assumed power.

With this last rejection of an agreement, plans for opening the port began. Newspapers announced that it was planned for Tuesday, July 3. Police Chief Quinn cautioned the public to stay away from the waterfront. He announced that there would be a total of seven hundred police on the waterfront. Regardless, thousands of people turned out to watch the events. At 11:00 A.M. on July 3 the police cleared the area around Pier 38. Roughly two and a half-hours later, the doors of Pier 38 rose and eight patrol cars came out followed by five trucks loaded with cargo. Police captain Thomas Hoertkorn held up a revolver and shouted "The port is open." Mike Quinn describes what happened next:

A deafening roar went up from the pickets...

With single accord the great mass of pickets surged forward. The Embarcadero became a vast tangle of fighting men. Bricks flew and clubs battered skulls. The police opened fire with revolvers and riot guns. Clouds of tear gas swept the picket lines and sent the men choking in retreat. Mounted police were dragged from their saddles and beaten to the pavement (Quinn, 1949, 104,105).

The trucks continued running but on the next day, July 4, the Industrial Association stopped due to the holiday. A press release in the newspapers stated that they planned to continue operations the next day. The trucking began again on July 5, what later came to be known as "Bloody Thursday." The police force had increased in size and was more heavily armed. Several hundred strikers charged a police line at the base of Rincon Hill located close to Pier 38. The strikers hurled rocks while the police shot tear gas bombs at the strikers, some of whom picked them up and threw them back at the police. Other strikers built barricades to block the police. Fires started in the brush. In the midst of this two men were shot to death. One died immediately, the other died shortly thereafter. By this point, Governor Merriam declared a state of emergency in San Francisco and ordered the National Guard to the waterfront. Some were stationed by nightfall. 
In the next week and a half, union after union voted for a general strike. It began on July 16, 1934. Similar to the response of employers and state officials in Seattle, the unionists promoting the general strike were portrayed as "communists" and alien "radicals" out to destroy the American way of life. The ILA characterized themselves in a different way during a radio address, which communicated the workplace collectivist principle of worker control.

This controversy goes further than just the longshoremen. It is the intrinsic right as well as the acquired right of every American worker to organize and control the job. The longshoremen are fighting labor's battle and not fighting for themselves alone. They are in the grip of a great struggle for human rights, human betterment and social advancement.

Assistant Secretary of Labor McGrady's made appeals to use the law to force the longshoremen to accept the terms of the President's mediation committee. Roosevelt ignored this, and the emphatic demands of employers and local officials, for coercive federal intervention during the general strike. The shipowners, mostly Republicans who opposed the New Deal, were informed that Roosevelt was on a ship in the mid-Pacific and could not be reached.

Similar to the Seattle case, threats to revoke local union charters began flowing in from international AFL officers. The labor leaders in San Francisco strongly opposed a general strike. But many had lost control of their unions due to the strength of conviction of the rank and file. The San Francisco Labor Council's Strike Strategy Committee created a General Strike Committee composed of five representatives from each of the city's AFL unions. This committee in turn voted to create an appointed executive committee. Bridges failed to win a nomination as vice chairman. Since the local officials could not stop the general strike, they instead decided to gain control of it in order to end it. The committee voted to create set about immediately continuing basic services that had shut down, such as the street cars and numerous restaurants, which gave the impression that the strike was dissipating just as it began. These actions led Harry Bridges, leader of the Maritime Strike Committee, to state that it was not the employers "but conservative labor that broke the strike." The general strike lasted roughly three days. After it ended, the Maritime Strike Committee maintained its stand in support of union controlled hiring halls and recognition of all maritime unions. The employers agreed to hire back all striking longshoremen. The longshoremen agreed to go back to work while arbitration continued.

The post-general strike terms of the federal labor board were accepted. In contrast to the federal response in Seattle in 1919, in the San Francisco case federal policies awarded concessions to organized workers who had engaged in militant direct action, by not only participating in a general strike but also riots in which they physically fought police, created barricades, and "took" Rincon Hill. In addition, the Roosevelt appointed National Longshoremen's Board revealed that the practices of the hiring hall had been corrupt and working conditions of the longshoremen dangerous. These findings convinced some federal officials and much of the public that concessions to the longshoremen were fair.

\footnotetext{
ANALYSIS

${ }^{14}$ ILA Radio Address, KGGC, San Francisco, California, July 20, 1934. International Longshoremen and Warehousemen's Union Library, San Francisco, California.
} 
At first glance it appears that these outcomes can be explained by differences in economic and political structures -- the more favorable economic bargaining position and state policies experienced by the longshoremen in San Francisco as opposed to the metal trades workers in Seattle. This is, in fact, accurate. But a closer look will reveal that political culture served as a foundation for the creation of the economic bargaining chips that won concessions as a result of the maritime and general strike in San Francisco, while similar strategic advantages were not feasible in the Seattle.

\section{The Cultural Foundation of Resources}

One prominent feature accounting for different outcomes was the more stable market position of the maritime workers in the San Francisco case as opposed to the position of metal trades workers dependent on war production. Trade and the movement of cargo was essential to the commerce of San Francisco. This was also true of other major port cities along the West Coast. For this reason it is clear that the occupational need for maritime workers was secure despite the depression, although the working conditions were insecure, with unionists subject to wage decreases, speed-ups, and the shape up method of hiring. The maritime strike had considerable economic impact due to the indispensability of maritime occupations, but foremost because the unions were able to successfully maintain a coast wide strike organized on an industrial rather than a craft basis. Cargo could not simply be shipped to another port. The impact of the strike was maximized within the first few weeks when the Teamsters refused to haul cargo on the waterfront, and the seamen and other maritime workers went out on strike for their own demands and in sympathy with the longshoremen.

It is in this context that the role of political culture in the creation of economic resources becomes apparent. Specifically, the workplace collectivist characteristics of One Big Union, rank and file control, and militant direct action were crucial to the winning concessions in the San Francisco case. If the maritime workers been receptive to the moderate craft unionism which ILA president Ryan represented, whose initial demand was for union recognition alone, what would have happened? There would have been no coast wide strike, federal intervention, general strike, coast wide contract, union controlled hiring hall, increased wages or reduction in the work day and week. Had the strike taken place at only one port and had only longshoremen participated, it would not have merited federal intervention, and would have had minimal economic impact. The craft orientation, preference for negotiations, bureaucratic decision-making and close relations between AFL elites and employers would have precluded the militant and tactics supported by the rank and file.

The creation of economic resources through the employment of workplace collectivist strategies, organizational forms and goals, is directly related to the extent of concessions won. The federally appointed mediation committees did not hand concessions, like the first coast wide contract in American history, over to the ILA. Only after a threatened coast wide strike did the first federal intervention take place when Roosevelt asked for a postponement and appointed a mediation committee. The concessions in the early agreements did not provide for a coast wide contract or joint control of the hiring hall with a union dispatcher. It was workplace collectivist organization and tactics that facilitated militant direct action with a scope and intensity that elicited increasingly generous concessions from the Roosevelt appointed National Longshoremen's Board.

Clearly favorable political climate and state actions were indispensable to success. Once federal intervention had taken place, the favorable state actions of Roosevelt and Perkins necessary for success. The point here is that federal intervention would not have taken place had it not been for developments that were shaped by the strategies and organizational forms characteristic of 
workplace collectivism. The strategic use of and resonance for this political culture among West Coast longshoremen best explains their advantageous economic position, which elicited federal intervention. Workplace collectivism was integral to the success of the San Francisco general strike and the coast wide maritime strike. A strike exhibiting such duration and solidaritywould have been much more difficult for East Coast Longshoremen to organize and maintain. 15

In Seattle in 1919, local, state and federal politicians, as well as state and national AFL officials took repressive action in response to the general strike and marginalized its leaders by describing them as "radicals." In San Francisco in 1934, the local and state politicians, city, state and national AFL officials, opposed the general strike and, like in Seattle, tried to marginalize its leaders by characterizing them as "communists." Yet there was a difference in the response at the federal level. Roosevelt administration officials, specifically Secretary of Labor Perkins and Roosevelt himself, did not accept this characterization. Rather than engaging in repressive measures, like sending in the army as had been done in Seattle, they facilitated the success of the coast wide maritime strike and the general strike by appointing labor boards that granted increasingly generous concessions as events unfolded.

Why didn't Roosevelt concede to the appeals of Assistant Secretary of Labor McGrady to use the law to force the longshoremen to accept the terms of the President's mediation committees? Was this because he did not want to jeopardize his labor constituency, all the more important in 1934 due to the loss of his business constituents? This is likely but a more complete answer considers the potential public relations impact of militant direct action.

Had Roosevelt attempted to bring the military in what would have happened? We already know that police violence and calling in the National Guard created the popular support for a general strike that the workplace collectivists had been pushing for in San Francisco. Riots had already taken place in response to "opening the port." Hostility increased and delegitimation of the state occurred as a result of the flagrant breach of neutrality with the use of the police and state militias on behalf of the employers. There had been disruption and threats of general strikes in Portland, Oregon and Seattle, Washington. Had the military been brought in it may have elicited general strikes and labor riots in a number of West Coast port cities. The militant coast wide strike of most maritime workers along with the general strike, demonstrated a level of labor organization, solidarity and militancy that no president had previously had to contend with. 16

The impact of such a response also has to be seen in light of the other militant labor struggles that took place throughout the country in 1934. Anti-New Deal Republicans had blamed Roosevelt's policies for these uprisings. In fact, labor insurgency in 1933-34 contributed to the withdrawal of business leaders from Roosevelt's New Deal coalition (Piven and Cloward, 1993, 84-87). The employers who were branding the Bridges faction as communists and calling for military intervention were Roosevelt's opponents. Had the president bought into their characterization of the Bridges faction, he would have legitimated his opposition's criticisms of his administration's policies as fueling radicalism. It's notable that Roosevelt never acknowledged that radicals had been responsible for the general strike. Rather he blamed the shipowners and "hot headed" and "inexperienced" young workers.

The San Francisco general strike and coast wide maritime strike succeeded in winning favorable concessions due to the economic resources generated by tying up most West Coast

\footnotetext{
${ }^{15}$ See Howard Kimeldorf's Reds or Rackets: The Making of Radical and Conservative Unions on the Waterfront (1988) for a discussion of the differences in market structure, occupational profiles, and the political orientations of the East and West Coast longshore workers.

${ }^{16}$ The closest experience was the Great Upheaval, a multi-state strike by railway workers in 1887 . But much of the strike was spontaneous, not organized. See Philip Foner's The Great Uprising 1877.
} 
ports, a favorable political climate and federal response, and resonance for workplace collectivist political culture among maritime workers in West coast ports.

\section{The Resource Foundation of Political Culture}

While the success of the San Francisco case provides insights into the cultural foundation for the creation of resources, the failure of the Seattle general strike to win concessions and the outcomes in both cases, shed light on the resource foundation for the flourishing, demise or institutionalization of political cultures. I will first address the need for a resource foundation to enable the transmission of political culture and how the absence of this limited the strategic options of metal trades workers in Seattle. This limitation combined with repressive state actions and an unfavorable political climate produced a context in which the metal trades strike and general strike did not produce concessions in the Seattle case. Finally, the resource foundation for the flourishing, institutionalization or demise of the political cultures will be assessed for each outcome.

\section{Resources and Cultural Transmission}

The ongoing coast wide strike, out of which the San Francisco general strike emerged, was a determining difference from the Seattle case. As previously discussed, workplace collectivist political culture informed the strategic decisions of longshore activists who organized the strike and the response of maritime workers is, in part, explained by a resonance for this political culture. Through this lens we see how political culture generated economic resources. But what is the relationship of resources to the presence and proliferation of political cultures?

Both the success, solidarity and longevity of the coast wide strike were due to the degree of social and occupational networking, job interchangeability, and mobility among workplace collectivist longshoremen and seamen at West Coast ports. The sense of collective identity and solidarity among West Coast unionists also grew out of a history of tension with Eastern AFL officials. Workplace collectivist inclinations that prioritized local control and autonomy facilitated a stronger identification with local and regional union organizations than with the Internationals. This was evidenced by the rank and file's refusal to accept ILA president Ryan's proposals and by the ILA granting of autonomy to West Coast ports as early as 1911 .

The point here is that the characteristics that enabled coast-wide organization and solidarity, in which workplace collectivist political culture was integral, were endemic to West Coast maritime unionism. Through this lens we see a specific type of political culture proliferate in relation to resources prevalent on the West Coast. While this is not the only region in which workplace collectivism flourished, when it did, there was a clustering and proliferation of this cultural form through the networking among specific occupations that was unique to the West Coast. In this region, the production, communication, and proliferation of this cultural form was constrained by resources. The resources took the form of certain types of occupations, occupational profiles and occupational networks that facilitated the production and communication of workplace collectivist political culture. This type of occupational interhangeability did not exist among East Coast occupations. Longshoremen and seamen led very separate lives and there was no logging industry similar to Seattle's, saturated with radical industrial unionists.

In the Seattle case, there was an industry-wide shipyard strike in process, but it was limited to one location while contracts could be filled at other ports. But why didn't workplace collectivists organize a coast wide strike of shipyard industries at all ports? The Seattle Union Record did mention an attempt to organize a shut down of shipyards. But this never materialized because workplace collectivist tendencies among Seattle unionists were the result of specific historical developments in the region. This was not true of all port cities along the West Coast. 
The metal trades workers within the shipyards did not experience the social and occupational networking that was part of the maritime political culture. They did not have a similar history. In other words, Seattle metal trades workers, as opposed to those in the maritime occupations, could not draw upon a common cultural lineage and shared orientation toward strategies because they were not in occupations that were interchangeable or directly linked them in some way. The cultural transmission that allowed for strategic success and solidarity among widely dispersed maritime workers was dependent on a specific type of resource base that did not exist among West Coast Metal Trades workers.

Further, the various maritime unions sought to gain concessions from the success of a coast wide strike. But it was exclusively the Puget Sound shipyard workers who had a wage decrease implemented by the federal government. Shipyard workers at other ports had nothing to gain from a coast wide strike except a show of solidarity. It is difficult enough to organize a coast wide strike and maintain solidarity when working people have something concrete to gain. But given both the lack of concessions to be gained for unionists in shipyards at other ports and the absence of strong workplace collectivist traditions in the metal trades industry, the occurrence of a coast wide strike of all shipyard workers in 1919 was not feasible.

Finally, state actors making decisions within the political climate of the depression and New Deal played an integral role in the concessions won in the San Francisco case whereas Seattle metal trades workers faced a repressive post-war political climate. It is an interesting question as to whether the outcome of the metal trades strike and general strike in Seattle would have been different had there been a coast wide metal trades strike. There are numerous examples of local, state and federal repression of labor insurgencies in American history. But organized, goal directed, industry-wide strikes that span cities and states present a different type of challenge to elites. Speculation aside, it is important to recognize the specific intersectional pattern of militant direct action with federal policies, response and facilitation in the San Francisco case that explains the winning of concessions.

The Flourishing, Demise and Institutionalization of Political Culture

In the Seattle and San Francisco cases, the tight linkage between resources, occupational networks and the perpetuation or dissipation of political cultures is hard to miss. Workplace collectivist tendencies were apparent among Seattle unionists prior to the war years. But from 1914 to 1919, Seattle's radical political culture flourished due to the resources from state subsidized jobs for war production. The already left leaning political culture in Seattle expanded with the growth of numerous new worker enterprises.

As mentioned earlier, Seattle experienced the post-war depression and closing of its government subsidized industries a year sooner than other West Coast ports. Most radical workers who had been drawn to the shipbuilding industries left Seattle to find jobs elsewhere. As a result, many of the workers' enterprises, some labor owned cooperatives which formed during the war production years, and some which formed shortly after the general strike, went under due to the decrease in resources and the loss of labor activists dedicated to their success. Workplace collectivism was instrumental to the generation of the general strike and it also played a role in its outcome, but not as much as external economic forces and state actions. Aside from the inevitable decrease in production due to the end of W.W.I., the federal government targeted Seattle. Ship contracts were canceled as a punishment for the general strike

The depression, which eventually hit all port cities in the early 1920s, led a number of workers to blame the general strike of 1919. Some of the more moderate unions disaffiliated with the Seattle Central Labor Council. All of these developments resulted in the eventual demise of workplace collectivist political culture, which flourished during the war years and 
shortly thereafter. By the late 1920s conservatives had gained dominance among organized labor in Seattle. New leaders emerged like business unionist Dave Beck of the Teamsters. But this is not to say that the workplace collectivist lineage disappeared from the political orientations of workers in Seattle or that the general strike presented no advantages for organized labor. Membership in most unions affiliated with the Seattle Central Labor Council grew until around the summer of 1920 (Berner, 1991, 309). Strikes continued at a high rate in Seattle after the general strike. Despite the growing factionalism within the SCLC there was a stronger solidarity among unionists who had participated in the general strike. There was a post-strike proliferation of labor cooperatives. It was only after the economy deteriorated that problems emerged.

However the relationship of political and economic resources to the fate of workplace collectivism was very different in the San Francisco case. The maritime workers had also exhibited strong workplace collectivist tendencies early in their history. Yet it wasn't until 193334 that these tendencies were harnessed into a powerful and successful coast wide movement. This occurred, in part, due to the political resources provided by Section 7a of the National Industrial Recovery Act that was passed in the summer of 1933. Political facilitation contributed to the vitality of the longshoremen union and the workplace collectivist political culture that flourished through the distribution of the Waterfront Worker, the dynamics of the rank and file convention, and the polarization and solidarity produced through the coast wide maritime strike, the riots, and the general strike.

Once the longshoremen agreed to accept arbitration and go back to work and the National Labor Board ruled that there would be joint control of the hiring hall by both longshoremen and employers but with a union dispatcher. As a result of the new method of hiring the employers could no longer blacklist "trouble makers" by not selecting them for work during the shape up. And of equal importance, due to the principle of rank and file control within the union, AFL officials were not able to eliminate "trouble makers" without being subject to the wrath of the rank and file. The fact that the Bridges faction was able to maintain their leadership positions within the ILA after the general strike was crucial to the institutionalization of workplace collectivist principles in the subsequent formation of the International Longshoremen and Warehousemen's Union.

After the general strike, workplace collectivist principles were both informally and formally institutionalized among longshoremen. Militant direct action among the rank and file was informally institutionalized as longshoremen, previously resigned to abusive conditions, orchestrated slow downs of production and walk-outs "at a moments notice" if demands were not met. These unauthorized actions caused considerable tension between the radical rank and file maritime unionists and moderate AFL officials. This tension continued for the next few years. After trying to change the AFL from within, the longshoremen eventually formed a new union -the International Longshoremen and Warehousemen's Union (ILWU) which affiliated with the Congress of Industrial Organization (CIO) in 1937. Participants in the rank and file strike committee during the general strike, most notably Harry Bridges, went on to become influential leaders in the new union. Bridges became the president and was continually reelected for years.

The ILWU was organized as an industrial union and the principles of rank and fileism and "One Big Union" were formally codified in their constitution. These principles were reaffirmed by the ILWU at the Tenth Biennial Convention held in San Francisco in 1953:

$\underline{\text { Rank \& Fileism }}$

A union is built on its members. The strength, understanding and unity of the membership can determine the union's course and its advancements...In brief, it is the 
membership of the union which is the best judge of its own welfare; not the officers, not the employers, not politicians...Above all this approach is based on the conviction that given the truth and an opportunity to determine their own course of action, the rank and file in 99 cases out of a hundred will take the right path in their own interests and in the interests of other people.

One Big Union

Labor unity is at all times the key for a successful economic advancement -anything that detracts from labor unity hurts all labor...

Workers are indivisible. There can be no discrimination because of race, color, creed, national origin, religious or political belief. Any division among workers can help no one but the employers...

To help any worker in distress must be a daily guide in the life of every trade union and its individual members. Labor solidarity means just that. Unions have to accept the fact that the solidarity of labor stands above all else, including even the socalled sanctity of contract...Every picket line must be respected as if it were our own... The days are gone when a union can consider dealing with single employers. The powerful financial interests of the country are bound together in every conceivable type of united organization to promote their own welfare and to resist the demands of labor...The employers of this country are part of a well organized, carefully coordinated, effective fighting machine. They can be met only on equal terms, which requires industry-wide bargaining and the most extensive economic strength of organized labor (ILWU,1963, $4,5)$.

The ILWU remains one of the most democratic unions in the United States today.

\section{IMPLICATIONS FOR THE STUDY OF CULTURE AND COLLECTIVE ACTION}

Recent studies of culture and social movements draw upon systemic and/or performative approaches (Johnston and Klandermans 1995). The former looks at entire cultural systems and how they serve to facilitate or constrain movements. The latter approach focuses on how cultural meaning is constructed by movements, often drawing upon the dominant cultural system to create alternative values, movement cultures and collective identity. For example, analysts have studied how beliefs about state legitimacy and traditions were drawn upon to construct challenges to the state (Walton 1992), how movement cultures are constructed through the process of building alternative institutions (Goodwyn1978) and engaging in collective action (Fantasia 1988), and how collective identities are constructed (Taylor and Whittier 1999: Green 1999). Such cultural production succeeds at enhancing the legitimacy, mobilization and solidarity of movements.

These approaches are useful for conceptualizing how workplace collectivism drew upon meanings within the dominant cultural system to challenge capitalist hegemony and demand greater control over the workplace and the wealth that their labor produced. It also provides a model for understanding how the resonance for workplace collectivist beliefs and practices increased solidarity and mobilization. While mobilization increases resources, not enough attention has been paid to how cultural practices interact with the movement environment to generate economic resources, as organizational practices did in the San Francisco case.

But the above stated approaches do not adequately provide a model for the explanation of how resources and occupational networks constrained political culture. As noted in the 
introduction of this paper, analysts of collective action have studied the relationship between political and economic resources and the generation and decline of social movements, yet resources are rarely directly linked to political culture as an analytically distinct phenomenon. 1 Culture is posited as either an emergent part of the social movement process (Fantasia 1988) ${ }^{17}$ or constructed through a preexisting resonance among collective actors (Snow and Benford, 1988; Tarrow, 1992). This study has identified how workplace collectivism was communicated over time by both labor organizations and through the occupational networks of individuals during times of movement abeyance. This occupational interchange was endemic to geographical regions due to the presence of specific occupations and networks among people either employed or seeking employment in these occupations. Workplace collectivism constructed and communicated through these occupational networks constituted the preexisting resonance for the selection of specific types of organizational forms, strategies and tactics that were crucial to social movement success in the San Francisco case. It is the resource base for the communication of a preexisting resonance or diffuse political culture that is being identified here. This is distinct from a resource base that facilitates social movement organizations.

Despite the progress being made through the incorporation of cultural analysis into studies of collective action, much current work, while recognizing the ongoing construction of meaning, treats political culture as epiphenomenon to the emergence of social movements and the resources that facilitate them. It analytically divorces political cultures, outside of a social movement context, from the people and networks that communicate them and from the political and economic resources out of which they are constructed and remain viable. In other words cultural production is not recognized as integrally related to the social location and access to resources of the human beings that construct, enact and communicate it. Such analyses reify political culture and propose an ahistorical understanding of the conditions of their emergence, decline or institutionalization.

Perhaps due to the refutation of overly deterministic variants of Marxism, current analyses

of culture and collective action often neglect the role of resources in cultural production while this recognition may be implicit in the analysis. As the cases in this study indicate, the cultural interpretation of life experience is produced by human beings who are socially located relative to access to resources. The enactment of practices are contingent upon preexisting cultural systems, structural arrangements, and the types of resources available in the actor's environment, including avenues for the communication of ideational content. But to argue that cultural production is constrained by access to resources is not to claim that content is determined by them.

While "communication networks" necessary for movement mobilization (Freeman $1973,1975,1999)$ and diffusion theory, used to analyze networks for the communication of movement ideas (McAdam and Rucht 1993), provide elements for a useful model, we must look outside the social movements literature for an approach that better explains the role of political culture in these cases.

In the field of cultural studies, the "institutional" approach has recognized the relationship between resources and cultural production. Analysts look at the emergence and institutionalization of cultural forms such as science, religion and education. Culture is not

\footnotetext{
${ }^{17}$ There is no doubt that changes in social conditions and the organization of social relations during collective action also changes the ideational frames by which activists interpret the world. But social movement actors are never devoid of preexisting cultural orientations which, combined with structural imperatives, shape "consciousness" and the types of desired changes.
} 
reified as something that is "out there" to be studied, but as selected forms which have emerged due to the expertise and resources of those who institutionalized them (Wuthnow, 1987).

Yet the above stated approach has focused exclusively on institutions. It is necessary to expand this analysis to all cultural production and to assess how the social location of activists, in relation to resources, occupational structures, and networks for the communication of ideational content, shape cultural forms. We must ask "What are the social locations of the producers? What role does resources, or lack of them, play in cultural production? How important is the occupational structure of a region to the production and viability of specific types of cultural forms? Such an approach, which best explains the role of political culture in the outcome of these cases, might best be described as a "locational" or "embodied" model of cultural production. Through this analytical lens the presence or absence of cultural forms within geographical regions is rendered comprehensible, including political cultures which inform the organizational forms, tactics and goals of human beings engaged in collective action.

Bibliography

Bakunin, Michael. 1970. God and the State. New York: Dover Publications, Inc.

Bellamy, Edward. 1915. Looking Backward 2000-1887. Chicago: M.A. Donohue \& Company.

Berner, Richard C. 1991. Seattle, 1900-1920: From Boomtown, Urban Turbulance, to Restoration. Seattle: Charles Press.

Bernstein, Irving. 1970. A History of the American Worker, 1933-1941: the Turbulent Years. Boston: Houghton Mifflin.

Brecher, Jeremy. 1997. Strike, (ed. By Manning Marable). Boston, MA: South End Press.

Brooks, John Graham. 1913. American Syndicalism: The IWW. New York, NY: Macmillan Company.

Bromley, David G. and Diana Cutchin. "The Social Construction of Subversive Evil: The Contemporary Anticult and Anti-Satanism Movements." In Waves of Protest: Social Movements Since the Sixties, eds. Jo Freeman and Victoria Johnson. Rowman \& Littlefield, 1999.

Chiles, Frederic Caire.1981.War on the Waterfront: The Struggles of the San Francisco Longshoremen, 
1851-1934. Dissertation, University of California, Santa Barbara.

Crook, Wilfred H. 1960. Communism and the General Strike. Hamden, CT: Shoe String Press, Inc.

Crook, Wilfred Harris. 1931. The General Strike: A Study of Labor's Tragic Weapon in Theory and Practice. Chapel Hill: The University of North Carolina Press.

Darcy, Sam. 1934. “The Great West Coast Maritime Strike.” The Communistt (July 13), 664-686, ILWU Library.

Dembo, Jonathan. 1978. A History of the Washington State Labor Movement. Dissertation, University of Washington.

Egan, Michael. 1975. "That's Why Organizing Was So Good" Portland Longshoremen, 1934: An

Oral. Master's Thesis, Reed College.

Eliel, Paul. 1934. The Waterfront General Strikes of San Francisco, 1934: a Brief History. San Francisco. California.Industrial Association of San Francisco.

Fantasia, Rick. 1988. Cultures of Solidarity. Berkeley: University of California Press.

Foner, Philip. 1977. The Great Uprising 1877. New York: Monad Press.

Friedhiem, Robert H. 1964a. The Seattle General Strike. Seattle: University of Washington Press.

Freidheim \& Freidheim. 1964b. "The Seattle Labor Movement, 1917-1920." Pacific Northwest Quarterly (October).

Friedman, Debra, and Doug McAdam. 1992. "Collective Identity and Activism: Networks, Choices, and the Life of a Social Movement." In Frontiers in Social Movement Theory, eds. Aldon Morris and Carol McClurg Mueller. New Haven: Yale University Press, 156-173.

Goodwyn, Lawrence. 1978. The Populist Movement: A Short History of the Agrarian Revolt in America. Oxford: Oxford University Press.

International Longshoremen's Association Representative (unnamed). 1934. Radio Broadcast, San Francisco, KTAB Radio Station, July 9, ILWU Library.

International Longshoremen's and Warehousemen's Union. 1963. The ILWU Story: Three Decades of Militant Unionism. Second Edition, revised. San Francisco, CA: ILWU Information Department, ILWU Library. 
Jenkins, Craig. 1999. "The Transformation of a Constituency into a Social Movement Revisited: Farmworker Organizing in California.” In Waves of Protest: Social Movements Since the Sixties, eds., Jo Freeman and Victoria Johnson. Lanham: Rowman \& Littlefield Publishers, Inc.

Jenkins, Craig and Charles Perrow. 1977.'Insurgency of the Powerless: Farm Worker Movements (1946-1972)." American Sociological Review 42:249-268.

Johnston, Hank and Bert Klandermans (eds.). 1995. Social Movements and Culture. Minneapolis: Univeristy of Minnesota Press.

Kimeldorf, Howard. 1988. Reds or Rackets: The Making and Unmaking of Radical and Conservative Unions on the Waterfront. Berkeley, CA: University of California Press.

Kropotkin, Petr. 1955. Mutual Aid: A Factor of Evolution. Boston: Extending Horizons Books.

Larana, Enrique, Hank Johnston, and Joseph R. Gusfield (eds.). New Social Movements: From Ideology to Identity. Temple University Press: Philadelphia, 1994.

Larrowe, Charles P. 1972. Harry Bridges: The Rise and Fall of Radical Labor in the United States. New York, New York: Lawrence Hill and Co.

Magden, Ronald E. 1991. A History of Seattle Waterfront Workers, 1884-1934. Seattle: ILWU, Local 19 and the Washington Commission for the Humanities.

McAdam, Doug. 1982. Political Process and the Development of Black Insurgency ,19301970. Chicago, IL: University of Chicago Press.

McAdam, Doug and Dieter Rucht. 1993. "The Cross National Diffusion of Ideas." ANNALS, AAPSS, 528, (July):56-74).

McCarthy, John D. and Mayer N. Zald. "Resource Mobilization and Social Movements: A Partial Theory." American Journal of Sociology 82: 1212-1241.

Melucci, Alberto. 1989. Nomads of the Present: Social Movements Individual Needs in Contemporary Society. Philadelphia: Temple University Press.

Morgan, Murray. 1982. Skid Road: An Informal Portrait of Seattle. Seattle: University of Washington Press.

Nelson, Bruce. 1990. Workers on the Waterfront: Seamen, Longshoremen, and Unionism in the 1930s. Chicago: University of Illinois Press.

Obershall, Anthony. 1973. Social Conflict and Social Movements. Englewood Cliffs, NJ: Prentice-Hall.

O'Connell, Mary Joan. 1964. The Seattle Union Record, 1918-1928: A Pioneer Labor 
Daily. Master's Thesis, University of Washington.

O'Conner, Harvey. 1964. Revolution in Seattle: A Memoir. New York: Monthly Review Books.

Perlman, Selig. 1923. History of Trade Unionism in the United States. New York: The Macmillan Company.

Proudhon, Pierre-Joseph. 1966. What is Property? An Essay into the Principle of Right and of Government. New York: Fertig.

Piven, Francis Fox and Richard A. 1993. Cloward. Regulating the Poor: The Functions of Public Welfare. New York: Vintage.

Quinn, Mike. 1949. The Big Strike. New York, NY. International Publishers.

Raineri, Vivian McGuckin. The Red Angel: The Life and Times of Elaine Black Yoneda, 1906-1988. New York, NY: International Publishers,1991.

Rosenthal, R. 1992. "Nothing Moved but the Tide.” Labor's Heritage, (Fall).

Sales, Roger. 1976. Seattle: Past and Present. Seattle: University of Washington Press.

Schwantes, Carlos A., 1979. "Leftward Tilt on the Pacific Slope: Indigenous Unionism and the Struggle Against AFL Hegemony in the State of Washington," Pacific Northwest Quarterly, (January).

Selvin, David F. 1996. A Terrible Anger: The 1934 Waterfront and General Strikes in San Francisco. Detroit: Wayne State University.

Press.

Sewell, William H. 1980. Work and Revolution in France: The Language of Labor from the Old Regime to 1848. Cambridge: Cambridge University Press.

Snow, David A., and E. Burke Rochford, Jr., Steven K. Worden, and Robert D. Benford.1986. "Frame Alignment Processes and Micromobilization, and Movement Participation.” American Sociological Review 51:464-481.

Snow, David A. and Robert, D. Benford. 1988. " Ideology, Frame Resonance and Participant Mobilization." In From Structure to Action: Social Movement Participation across Cultures, (eds.) Bert Klandermans, Hanspeter Kriesi and Sidney Tarrow. Greenwich, CN: JAI Press

Snow, David A. and Robert D. Bedford. 1992. "Master Frames and Cycles of Protest." In Aldon D. Morris and Carol McClurg Mueller's Frontiers in Social Movement Theory. New Haven: Yale University Press,133-155. 
Sorel, Georges. 1950. Reflections on Violence. New York: Cillier-MacMillan.

Tilly, Charles. 1978. From Mobilization to Revolution. New York: Random House.

Thompson, E.P.. 1963. The Making of the English Working Class. New York, NY: Vintage Books.

Voss, Kim. 1993. The Making of American Exceptionalism: The Knights of Labor and Class Formation in the Nineteenth Century. Ithaca, NY: Cornell University Press.

Walton, John. 1992. Western Times and Water Wars: State, Culture, and Rebellion in California Berkeley, CA:University of California Press.

Wuthnow, Robert. 1987. Meaning and Moral Order: Explorations in Cultural Analysis.

Berkeley:

University of California Press. 